\title{
Research on the Teaching Mode of Deep Integration of Production and Education in Logistics Major of Higher Vocational Colleges
}

\author{
Liu Lijuan \\ Yunnan Vocational Institute of Energy Technology, Qujing, China 655000
}

Keywords: integration of production and education; higher vocational education; logistics major; talent training

\begin{abstract}
With the continuous development of social science and technology and the continuous improvement of people's living standards, the logistics industry has also achieved rapid development, which has put forward higher requirements for graduates of logistics majors in higher vocational colleges. In order to ensure that graduates majoring in logistics can adapt to the demands of the logistics industry for their professional knowledge and comprehensive quality, it is necessary for higher vocational colleges to carry out scientific and effective teaching practice reform. This paper introduces the relevant connotation and status quo of the "production and education integration" of higher vocational education system, and deeply analyzes the teaching mode of higher vocational logistics under the mechanism of integration of production and education, in order to cultivate more talents in logistics majors in higher vocational colleges, and promote the further development of higher vocational education.
\end{abstract}

\section{Introduction}

The purpose of teaching in higher vocational colleges is to train a group of high-quality talents with high theoretical knowledge and practical ability in production, service and management for related industries. The integration of production and education and the combination of engineering and learning are the inevitable requirements of higher vocational education. At the same time, it also pointed out the direction for the training of logistics professionals and the reform of practical teaching in higher vocational colleges. Therefore, taking the vocational education reform mechanism combined with production and education as an opportunity, it is particularly urgent to carry out the reform of the logistics professional practice teaching and optimize the practical curriculum system ${ }^{[1]}$. 
2. The connotation and present situation of the combination of production and education in higher vocational education

\subsection{The connotation of "Integration of Production and Education" in higher vocational education}

The integration of production and education should be based on the combination of good production and education, the deepening of the combination of production and education, and the deep cooperation between vocational education and industry. The "integration of production and education" in higher vocational education is a fusion mode of production, learning and research. It mainly integrates industry and teaching, and builds higher vocational specialties into industrial operating entities that integrate talent cultivation and scientific research. Promoting the integration of production and education in higher vocational colleges is of great help to solve the problem of the disconnection between education and actual employment needs. On the other hand, the combination of production and education has played a role in vocational education to a certain extent, making the society of vocational education Value is better played.

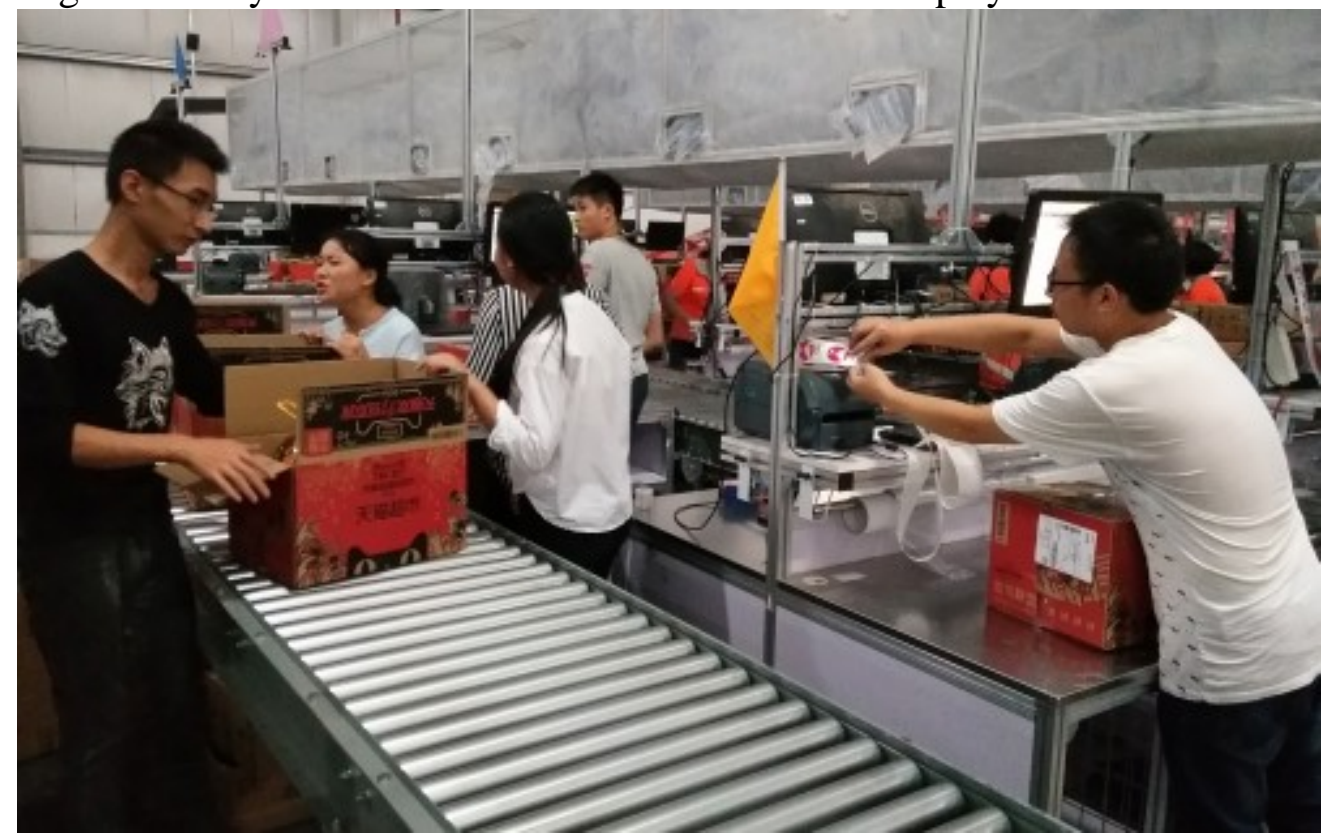

Figure 1 Logistics students operate in the company's internship workshop

\subsection{The status quo of "Integration of Production and Education" in higher vocational education}

In foreign countries, the integration of production and education in higher vocational education has been practiced for a long time and has achieved great results. In Germany, the "dual system" of the system of production and education has been established. In the United States, the combination of higher education and the combination of production and education in the "work and study" has cultivated a large number of professional talents for American companies. In Japan and Korea, vocational schools are completely enterprises hold, and enterprises cultivate professional talents. At present, the combination of production and education in higher vocational education in China is more diverse. There are school-enterprise cooperation, work-study combination, joint education, and school-enterprise joint training base. These teaching modes have a shallow combination of production and education. Teaching pays attention to form and does not pay attention to content. 
This combination of higher vocational education and teaching has achieved certain results in many years of practice, but it is still not perfect in professional direction, internship training and teacher training. Professional talents are still far from meeting the talent needs of enterprises ${ }^{[2]}$.

\section{Based on the "integration of production and education", the teaching model of logistics professional education in higher vocational colleges}

Under the establishment of the mechanism of integration of production and education, on the basis of the vocational education mode of higher vocational logistics, combined with the actual requirements of social economic development for logistics talents, systematically adjust the teaching system of logistics management. To build a platform for cooperation between industry and education as a guide to promote the integration of production and education, to achieve the integration of logistics management and talent training in higher vocational education, and to promote the further development of higher vocational logistics.

\subsection{Building a platform for cooperation between industry and education}

In the construction of logistics management majors in higher vocational colleges, in order to meet the needs of talent cultivation in the industry, it is necessary to integrate logistics management education with industry as much as possible, build a platform for cooperation between industry and education, and realize the joint development of logistics management and talent training in higher vocational schools. In the construction of the production and education cooperation platform, higher vocational colleges need to grasp the mutual needs of the logistics industry and logistics management professional construction, and establish a platform for benefit sharing. In the face of insufficient capacity and backward teaching mechanism, higher vocational colleges need to be good at using the advantages of policies, using the bridge between the government and industry to deepen the cooperation between schools and enterprises, and further promote the sharing of information in the industry. Higher vocational colleges and industries need to adhere to the principle of mutual benefit, build a platform for cooperation between industry and education for talent cultivation, establish a mechanism for sharing resources and benefits, and strengthen the link between higher vocational colleges and industries to realize higher vocational colleges. Long-term cooperation and win-win cooperation with the industry ${ }^{[3]}$.

\subsection{The platform of cooperation between industry and education promotes the construction of logistics specialty and the cultivation of talents}

Higher vocational colleges and enterprises need to focus on constructing substantive exchange and cooperation projects, formulate corresponding systems for exchanges and cooperation between the two sides, improve cooperation mechanisms, implement industry-university cooperation, deepen integration of production and education, and promote the construction of logistics management majors. To enable the professional logistics management profession to achieve substantial development.

In the cooperation between higher vocational colleges and industry, the following cooperative carriers can be established: establishing a joint training base, integrating the training base into the construction of logistics management, strengthening small class training and accelerating the establishment of a training system to achieve the cultivation of logistics management talents; The introduction of enterprises directly into the industrial parks of the school, the combination of enterprise training and professional education, the cultivation of talents according to the employment standards of enterprises, and the training of talents in line with the needs of enterprises; 
Establish a logistics technology R\&D center within the school. Students in higher vocational colleges research logistics technology in the research center, share logistics technology and information resources, and provide corresponding information and technology services for logistics enterprises, thus promoting the integration of production and education in higher vocational colleges. The formation of the experience and resources for the construction of professional logistics management and talent training ${ }^{[4]}$.

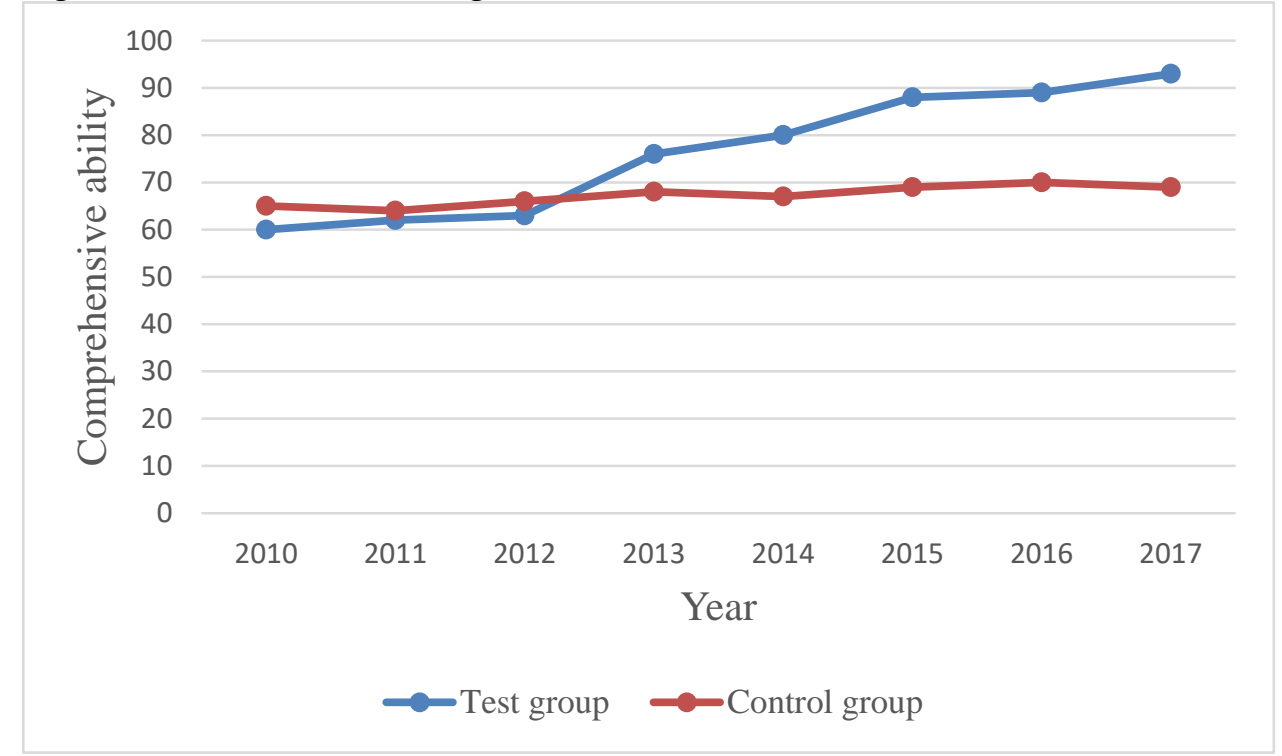

Figure 2 The effect of integration education of production and education in logistics majors in higher vocational colleges

\subsection{Higher vocational logistics construction and talent training}

In the construction of professional logistics management and talent training, it is necessary to rely on the production and education cooperation platform or training base to develop a complete logistics management professional teaching mechanism and teaching curriculum system, and in the establishment of the teaching curriculum system, especially pay attention to the establishment of the training system.

In the construction of the practical teaching system, it is necessary to pay attention to: the practical training course needs to take the actual operation management of the logistics enterprise as a reference, adopt the general standard of the logistics industry, and adhere to the actual operation effect of the logistics management is the only criterion for testing the effectiveness of the course teaching; Establish a comprehensive logistics management professional teaching system. In the teaching system, it needs to include warehousing, transportation, barcode recognition operation and intermediate route optimization operation. It needs to meet the basic operational requirements of logistics management operations and the technical requirements of primary management ${ }^{[5]}$.

\section{Conclusions}

Under the mechanism of integration of production and education, the practical teaching system of logistics management is based on the characteristics of logistics profession and the new demand for talents in the logistics industry in the new era. In the teaching process, more emphasis is placed on the cultivation of students' learning ability, innovation ability and practical ability. Therefore, it is necessary to actively explore and make efforts to innovate, carry out reform and innovation with the combination of production and education, guide the exploration of new teaching modes, and 
strive to optimize the teaching process, so as to promote the development of logistics specialty in higher vocational colleges.

\section{References}

[1] Zou Min. Discussion on the Practice of Production and Education Integration in Logistics Management Specialty of Higher Vocational Education[J]. Times Education, 2014(21):9-9.

[2] Gao Zhihua, Qi Xueru, Wang Yushuang. Research on the Evaluation System of Students' Learning Quality in Higher Vocational Colleges under the Mode of Productive Education Integration[J]. Hebei Vocational Education, 2017(1): 21-25.

[3] Duan Huilan, Cao Yanping. Research on the Construction of Logistics Management Professional Group with Deep Integration of Production and Education[J]. Journal of Higher Education, 2016(6): 50-51.

[4] Yin Yingjie, Li Hui. Exploration and Practice of Deep Integration Model of Higher Vocational Education in Production and Education[J]. Journal of Shijiazhuang Railway Vocational and Technical College, 2015, 14(2): 108-112.

[5] Song Xiangdong, Zhang Yuping, Tao Quanjun. Research on Operational Mechanism of Deep Integration of Production and Teaching in Higher Vocational Education[J]. Journal of Guangdong Vocational College of Communications, 2017, 16(1): 121-123. 